\title{
Dissociation of Natriuresis and Diuresis and Heterogeneity of the Effector System of Atrial Natriuretic Factor in Rats
}

\author{
Roland C. Willenbrock, Johanne Tremblay, Raul Garcia, and Pavel Hamet
}

Clinical Research Institute of Montreal, Montreal, Quebec, Canada H2W $1 R 7$

\begin{abstract}
The hypotensive, natriuretic, and diuretic actions of human atrial natriuretic factor-(99-126) (hANF) are accompanied by an elevation of cyclic guanosine monophosphate (cGMP) in plasma and urine. However, the oxidized hANF analogue, human [Met-O $\left.{ }^{110}\right]$ ANF-(99-126) (Met-O-ANF), has been reported to be unable to increase cGMP (Biochem. Biophys. Res. Commun. 128:538-546). We employed this oxidized peptide to evaluate the relationship between its biological effects and cGMP generation, with cGMP serving as a marker of the recognized property of ANF to stimulate particulate guanylate cyclase. Met-O-ANF appeared to be a partial agonist, exhibiting a decreasing order of relative potency of hypotensive, vasorelaxant, diuretic, and natriuretic functions compared to hANF. A lower degree of cGMP increases was achieved by this analogue in cultured smooth muscle and endothelial cells. Met-O-ANF doses, which led to a significant increase in diuresis, were neither natriuretic nor accompanied by an increase of urinary cGMP. We were thus able to dissociate the diuretic and natriuretic effects of ANF. High doses of the oxidized analogue were required to elevate cGMP levels in plasma and urine. In isolated kidney fractions, Met-O-ANF's action on cGMP was significantly lower in glomeruli (fivefold less), virtually absent in the collecting duct, yet only slightly different (20\% less) in thick ascending limb. Our results indicate that the diuretic and natriuretic effects are exerted at distinct sites, with only the natriuresis being related to an increase of extracellular cGMP. The variability of differential potency of biological and biochemical effects from tissue to tissue of these two forms of human ANF support the notion of the heterogeneity of the ANF effector system.
\end{abstract}

\section{Introduction}

The cardiac hormone atrial natriuretic factor (ANF) ${ }^{1}$ induces natriuresis and diuresis, possesses vasorelaxant properties,

Address reprint requests to Dr. Hamet, Clinical Research Institute of Montreal, 110 Pine Avenue West, Montreal, Quebec H2W 1R7, Canada.

Received for publication 7 December 1987 and in revised form 3 August 1988.

1. Abbreviations used in this paper: $\mathrm{ADH}$, antidiuretic hormone; $\mathrm{ANF}$, atrial natriuretic factor; hANF, human ANF-(99-126); Met-O-ANF, human [Met-O ${ }^{110}$ ]ANF-(99-126); MIX, methylisobutylxanthine; PTH, parathormone.

J. Clin. Invest.

(C) The American Society for Clinical Investigation, Inc.

0021-9738/89/02/0482/08 \$2.00

Volume 83, February 1989, 482-489 lowers blood pressure and decreases plasma renin and aldosterone levels (for review, see 1-3). Natriuresis and diuresis are probably produced by complex mechanisms, including a specific sensitivity of the renal artery to ANF, leading to elevated renal blood flow $(4,5)$ and an increased glomerular filtration rate (6). The latter may be due to enhanced filtration pressure elicited by selective vasodilation of the afferent arterioles and vasoconstriction of the efferent arterioles $(7,8)$. In addition, ANF apparently inhibits tubular sodium reabsorption, especially at the level of the medullary collecting duct (9-11). Although no receptors have been found on proximal tubules (12, 13), lithium excretion is reported to be increased, suggesting either decreased reabsorption in the proximal tubules (14) or an effect secondary to hemodynamic changes.

Enhanced diuresis and natriuresis after ANF infusions parallel the elevation of plasma, urinary and renal tissue cGMP levels in rats (15), monkeys (16), and humans (17). Particulate guanylate cyclase has been identified as a target enzyme of ANF's action in the glomeruli and collecting ducts (18-20). ANF-induced vasorelaxation has been correlated with a rise in cGMP $(21,22)$, and vascular smooth muscle cells show heightened intracellular cGMP values (23). Inhibition of renin release by ANF has also been reported to be cGMP-mediated (24). It has been proposed that CGMP is a second messenger for the transmission of ANF's actions $(15,16,20,21,23)$.

Human ANF-(99-126) (hANF) is identical to canine, porcine, and bovine ANF but differs from rat, mouse, and rabbit ANF in that isoleucine in position 110 is replaced by methionine $(25,26)$. This difference does not influence its glomerular binding characteristics (27). However, hANF can be oxidized at this methionine site (28) and is converted into methoxy-sulfoxide ANF, human [Met-O ${ }^{110}$ ]ANF-(99-126) (Met-O-ANF). It is conceivable that this type of oxidation occurs in vivo. Met-O-ANF has been reported not to increase cGMP in vascular smooth muscle cells while its binding is only slightly less than that of the parent compound (29). These considerations led us to evaluate the usefulness of Met-O-ANF as a potential tool to relate the specific biological properties of ANF with the cGMP system.

\section{Methods}

$A N F$. Synthetic human ANF-(99-126) (hANF) and human [Met$\mathrm{O}^{110}$ ]ANF-(99-126) (Met-O-ANF) were purchased from the Institut Armand-Frappier, Laval, Quebec, Canada. They were dissolved at a concentration of $10^{-4} \mathrm{M}$ in $0.1 \mathrm{~N}$ acetic acid, and kept frozen at $-35^{\circ} \mathrm{C}$.

Animals. Male Wistar rats $300-350 \mathrm{~g}$, purchased from Charles River Canada, St-Constant, Quebec, Canada, were used in all the studies. They were fed normal Purina Rat Chow and allowed free access to tap water.

Measurements of diuresis, natriuresis, and cGMP excretion. The jugular vein and urinary bladder were catheterized with PE 50 polyethylene tubing under sodium pentobarbital anesthesia $(40 \mathrm{mg} / \mathrm{kg}$ body 
wt i.p.). Glucose $5 \%$ was infused at a flow rate of $3 \mathrm{ml} / \mathrm{h}$ throughout the experiment. After a 45-min stabilization period, urine samples were taken during a 20 -min preinfusion control period (C). Either hANF or Met-O-ANF was then injected as a bolus via the jugular vein at 20 -min intervals in three escalating doses $(0.5,1.0$, and $2.0 \mu \mathrm{g})$. Urine samples were collected for $20 \mathrm{~min}$ after each injection and during an additional 20-min recovery period (postinjection, $\mathrm{P}$ ), starting $20 \mathrm{~min}$ after the last treatment. Urinary volume was measured by weight, urinary cGMP levels were determined by radioimmunoassay $(30,31)$, as previously described (15), and $\mathrm{Na}^{+}$and $\mathrm{K}^{+}$concentrations were assessed by flame photometry.

Blood pressure measurements. In an additional group of Wistar rats, blood pressure was monitored continuously via a pressure transducer (Gould Statham P23ID; Statham Instruments, Oxnard, CA) connected to the carotid artery of anesthetized rats and recorded by a polygraph (model 7; Grass Instruments, Inc.). Control blood pressure was measured during an initial 20 -min period, followed by 20 -min intervals after the injection of the vehicle or of increasing doses $(0.5$, 1.0 , or $2.0 \mu \mathrm{g}$ ) of either hANF or Met-O-ANF.

Determination of plasma cGMP. Blood samples $(500 \mu \mathrm{l})$ were drawn from the carotid artery into tubes containing EDTA (final concentration $7 \mathrm{mM}$ ), centrifuged at $2,500 \mathrm{~g}$ for $15 \mathrm{~min}$. The plasma was kept at $-35^{\circ} \mathrm{C}$ until the cGMP measurements, when it was deproteinized with perchloric acid (final concentration $0.5 \mathrm{~N}$ ) and cGMP was extracted with alumina (AG 7) and Dowex (AG 50W-X8) columns before assessment by radioimmunoassay. In one set of experiments, blood for the cGMP determinations was collected at the end of a 20-min control period and $5 \mathrm{~min}$ after the injection of the vehicle (acetic acid) or of either $2.0 \mu \mathrm{g}$ of hANF or Met-O-ANF. To eliminate an eventual hemodynamic effect provoked by the blood drawings, we performed a separate experiment using bolus injections of $2.0 \mu \mathrm{g}$ Met-O-ANF without prior blood sampling, and investigated the time course of the cGMP levels by collecting blood either $90 \mathrm{~s}$, or $3,5,10$, or 30 min after the Met-O-ANF injection. A third set of experiments was undertaken with a cumulative dose of $3.5 \mu \mathrm{g}$ of hANF or Met-O-ANF $(0.5,1.0$, and $2.0 \mu \mathrm{g}$, injected in 20 -min intervals). Plasma cGMP levels were measured $5 \mathrm{~min}$ after the last injection.

Vasorelaxation of aortic strips. After sodium pentobarbital anesthesia $(40 \mathrm{mg} / \mathrm{kg}$ body wt i.p.), the thoracic aorta was rapidly excised, fat and connective tissue were gently trimmed off, and the aorta was helically cut into $1-\mathrm{mm} \times 20$-mm strips. These were mounted between a fixed base and a force displacement transducer (Grass, FT-03C) in a $20-\mathrm{ml}$ tissue bath containing continuously oxygenated $\left(95 \% \mathrm{O}_{2} / 5 \%\right.$ $\mathrm{CO}_{2}$ ) Krebs solution (in mM: $\mathrm{NaCl} 123, \mathrm{KCl} 2.2, \mathrm{MgCl}_{2} 0.5, \mathrm{NaH}_{2} \mathrm{O}_{4}$ 0.4, $\mathrm{CaCl}_{2}$ 5.0, glucose 5.0, $\mathrm{NaHCO}_{3} 25.0$ ) at $37^{\circ} \mathrm{C}$ and $\mathrm{pH}$ 7.4. A tension of $1.0 \mathrm{~g}$ was applied to each strip and a dose-response curve for norepinephrine was constructed. At the half-maximal contraction obtained with norepinephrine $(36 \pm 3.9 \mathrm{pmol} / \mathrm{liter})$, relaxation was induced with either hANF or Met-O-ANF, which were added to the tissue in increasing concentrations at 2-min intervals.

cGMP production in different kidney fractions. Rat glomeruli were obtained from Wistar rats (280-300 g) which were pentobarbital-anesthetized before removal of the kidneys. The cortex was separated, sliced and placed into Krebs-Henseleit saline (KHS; in mM: $\mathrm{NaCl} 139$, $\mathrm{KCl} 3.7, \mathrm{KH}_{2} \mathrm{PO}_{4} 1.4, \mathrm{MgSO}_{4} 2.9, \mathrm{CaCl}_{2} 5.9, \mathrm{NaHCO}_{3} 58.0$ ) at $4^{\circ} \mathrm{C}$. It was gently grounded through the successive molecular sieves of a 250 and $150-\mu \mathrm{m}$ mesh and passed-through fractions were sieved at $63 \mu \mathrm{m}$. The retained tissue was washed three times with KHS and then verified under phase-contrast light microscope. It demonstrated to be $90-95 \%$ pure intact glomeruli fractions. The rat glomeruli were incubated in the presence of increasing doses of ANF with $500 \mathrm{mmol}$ concentration of methylisobutylxanthine (MIX) for $4 \mathrm{~min}$. The incubation was stopped by addition of $1 \mathrm{ml}$ of $1 \mathrm{~N}$ perchloric acid and rapid freezing in liquid nitrogen. Kidneys from anesthetized mongrel dogs were rapidly removed and placed in gassed $\left(95 \% \mathrm{O}_{2} / 5 \% \mathrm{CO}_{2}\right) \mathrm{KHS}$ at $4^{\circ} \mathrm{C}$. They were decapsulated, cut into slices, and the outer cortex and red and white medulla were carefully dissected. Each fraction was sliced with a Stadie-Riggs microtome, and washed with KHS. The cortex was digested with collagenase at $37^{\circ} \mathrm{C}$ for $45 \mathrm{~min}$, the red and white medulla for $60 \mathrm{~min}$. The cortex suspension was washed with KHS and passed through a $90-\mu \mathrm{m}$ mesh sieve (32). The glomeruli were retained and further purified by successive washings. Thick ascending limbs were obtained directly from digestion of the red medulla (33). Distal collecting ducts were derived from the white medulla. To verify the proper isolation of these nephron segments, microscopic and enzymatic methods were used (34). The usual degree of purity was more than $95 \%$ for the glomeruli and $100 \%$ for the collecting ducts. For cGMP stimulation, $200-400 \mu \mathrm{g}$ glomeruli, $1.2 \mathrm{mg}$ ascending limb or $300 \mu \mathrm{g}$ collecting duct were preincubated with $250 \mu \mathrm{KHS}$ at $37^{\circ} \mathrm{C}$ for $10 \mathrm{~min}$, then incubated for $4 \mathrm{~min}$ with increasing concentrations of hANF or Met-O-ANF in the presence of $100 \mu \mathrm{M}$ MIX (18). The incubation was stopped by the addition of $1 \mathrm{ml}$ of $1 \mathrm{~N}$ perchloric acid. After extraction, cGMP was measured by radioimmunoassay, as previously described (31).

cGMP production by aortic smooth muscle and endothelial cells. Rat aortic smooth muscle cells were obtained from adult, male Wistar rats by an explant method (35). Bovine aortic endothelial cells were generously donated by Dr. Patricia D'Amore (Harvard Medical School, Boston, MA). Both cell types were cultured at $37^{\circ} \mathrm{C}$ in Dulbecco's modified Eagle medium (DME) with $10 \%$ calf serum, $50 \mathrm{U} / \mathrm{ml}$ penicillin and $50 \mu \mathrm{g} / \mathrm{ml}$ streptomycin under $95 \% \mathrm{O}_{2} / 5 \% \mathrm{CO}_{2}$. When the cells became confluent, they were trypsinized and passaged into $75-\mathrm{cm}^{2}$ culture flasks. Cells between the 14th to 20th passages were used for the experiments and passaged into $35-\mathrm{mm}$ petri dishes. When confluence was reached (3-4 d), they were washed twice in DME, without calf serum, and incubated with different concentrations of ANF for $120 \mathrm{~min}$ at $37^{\circ} \mathrm{C}$ under $95 \% \mathrm{O}_{2} / 5 \% \mathrm{CO}_{2}$. The 120 -min time period was selected since we have previously demonstrated (16) that even very short ( $1 \mathrm{~min}$ ) exposure to ANF (which can be either removed or degraded) leads to a continuous accumulation of extracellular cGMP, making the amplification of the response optimal after $2 \mathrm{~h}$. At the end of incubation, the extracellular medium was aspirated and diluted in an equal volume of $1 \mathrm{mM}$ MIX and $20 \mathrm{mM}$ EDTA. Samples were frozen at $-35^{\circ} \mathrm{C}$ until cGMP determination by radioimmunoassay.

Statistics. The results are expressed as mean \pm SEM. Comparisons were made by one- or two-way analysis of variance with a posteriori comparisons according to Bonferroni's method. The rank order Wilcoxon test was used to analyze the mean arterial blood pressure and differences in plasma cGMP levels. Differences were considered to be significant at $P<0.05$.

\section{Results}

Diuresis, natriuresis, and urinary cGMP excretion. Bolus injections of $0.5,1.0$, and $2.0 \mu \mathrm{g}$ hANF induced a significant ( $P$ $<0.001$ ), dose-dependent increase of urinary volume (maximal 6-fold), natriuresis (maximal 10-fold) and cGMP excretion (maximal 5-fold) when compared to control values $(C$, Fig. 1). During the postinjection control period (P), urinary volume and sodium returned to preinjection levels, while urinary cGMP remained slightly elevated. Met-O-ANF induced a significant threefold increase of urinary volume $(P<0.05)$. Though this stimulation was less pronounced than with $\mathrm{hANF}$, it lasted longer throughout the recovery period. In contrast to hANF $(P<0.01)$, there was no increase in urinary sodium excretion after the Met-O-ANF injections, and a $50 \%$ decrease (not significant) was even observed at the end of the final control period. Also contrary to the stimulation evoked by hANF, urinary cGMP levels were not influenced by Met-O-ANF at the concentrations mentioned above $(P$ $<0.001$, when compared to hANF). This dissociation appeared to be dose-dependent; with higher doses of Met-O-ANF 



Figure 1. Diuresis, natriuresis and urinary cGMP excretion in Wistar rats after injection of $0.5,1.0$, and 2.0 $\mu \mathrm{g}$ of hANF or Met-OANF. The values are means \pm SEM, $n=8 . * P$ $<0.05$ when compared to control; $\ddagger P<0.05$ when compared to hANF; $\S P<0.01$ when compared to hANF.

(three times $2 \mu \mathrm{g}$ ), we were able to produce a slight increase il. natriuresis and cGMP excretion (data not shown). Thus, the diuresis elicited by Met-O-ANF was not paralleled by either natriuresis or enhanced cGMP excretion.

The correlations between doses of hANF and Met-O-ANF and diuresis, natriuresis and cGMP excretion are shown in Table I.

Arterial blood pressure. Mean arterial blood pressure did not change significantly upon injection of $0.5 \mu \mathrm{g}$ of either hANF or Met-O-ANF. After doubling the dose, blood pressure was reduced by $17 \%$ and $13 \%$ by $1.0 \mu \mathrm{g}$ of hANF and Met-OANF, respectively (Table II). Subsequent injection of $2.0 \mu \mathrm{g}$

Table I. Correlation between Doses of ANF, Diuresis, Natriuresis and Urinary cGMP

\begin{tabular}{ccc} 
& hANF & MET-O-ANF \\
\hline A ANF/cGMP & $0.78^{\S}$ & -0.18 \\
ANF/diuresis & $0.58^{\ddagger}$ & $0.44^{*}$ \\
ANF/natriuresis & $0.60^{\ddagger}$ & -0.11 \\
B cGMP/diuresis & $0.41^{*}$ & 0.06 \\
cGMP/natriuresis & $0.39^{*}$ & 0.15 \\
Natriuresis/diuresis & $0.81^{\S}$ & 0.31
\end{tabular}

In $A$, either hANF or Met-O-ANF was injected at increasing doses $(0.5 \mu \mathrm{g}, 1.0 \mu \mathrm{g}, 2.0 \mu \mathrm{g})$. Correlations were calculated between these doses and the resulting urinary cGMP excretion, diuresis, or natriuresis, as reported in Fig. 1 (i.e., for the three doses used in each of eight animals, $n=24$ ). In $B$, the correlations between the natriuretic, diuretic, and cGMP response to either hANF or Met-O-ANF (as shown in Fig. 1) were calculated. ${ }^{*} P<0.05 ;{ }^{\ddagger} P<0.01 ;{ }^{\S} P<0.001$.

Table II. Effect of hANF and Met-O-ANF on Mean Arterial Blood Pressure

\begin{tabular}{|c|c|c|c|c|}
\hline & \multirow[b]{2}{*}{ Basal } & \multicolumn{3}{|c|}{ Dose injected } \\
\hline & & $0.5 \mu \mathrm{g}$ & $1.0 \mu \mathrm{g}$ & $2.0 \mu \mathrm{g}$ \\
\hline Vehicle & $103 \pm 8$ & $95 \pm 9$ & $102 \pm 10$ & $99 \pm 9$ \\
\hline hANF & $103 \pm 5$ & $100 \pm 4$ & $86 \pm 8^{*}$ & $83 \pm 8^{*}$ \\
\hline Met-O-ANF & $96 \pm 13$ & $90 \pm 11$ & $84 \pm 10^{*}$ & $81 \pm 10^{*}$ \\
\hline
\end{tabular}

Mean arterial pressure of Wistar rats 20 min after injection of vehicle (acetic acid), hANF or Met-O-ANF. ${ }^{*} P<0.05$, rank-order Wilcoxon test, compared to control values. The data are expressed in millimeters of mercury as mean $\pm \mathrm{SEM}, n=5$.

lowered it by $19 \%$ and $16 \%$, respectively. These decreases in blood pressure were significant $(P<0.05)$ after bolus injection of 1.0 and $2.0 \mu \mathrm{g} \mathrm{hANF}$ as well as of Met-O-ANF.

Plasma cGMP levels. To investigate whether the absence of urinary cGMP excretion in the presence of a diuretic action of Met-O-ANF was due to a lack of cGMP production or to a difference in cGMP excretion, plasma cGMP levels were determined $5 \mathrm{~min}$ after injection of $2.0 \mu \mathrm{g}$ of either Met-O-ANF or hANF. As reported earlier (15), hANF increased plasma cGMP about fivefold $(P<0.001$, Table III) when compared to preinjection values. In contrast to hANF, injection of $2.0 \mu \mathrm{g}$ Met-O-ANF did not elevate plasma cGMP levels. The effect of a single injection of $2.0 \mu \mathrm{g}$ Met-O-ANF on cGMP was then determined at various time intervals without previous blood drawings in order to exclude early or late increases of plasma cGMP levels. No peak of cGMP occurred and plasma levels were even lower $30 \mathrm{~min}$ after injection, when compared to control values (Table IV). However, when cumulative doses $(0.5,1.0,2.0 \mu \mathrm{g})$ of Met-O-ANF were injected, the increase of cGMP values was twofold, whereas the same dose of hANF induced a sixfold increment $(P<0.01)$. The difference in the cGMP response between hANF and Met-O-ANF was signifcant $(P<0.01$, Table V).

Vasorelaxation of aortic strips. In accordance with previously reported observations (36), hANF produced a $100 \%$ relaxation of aortic strips contracted by norepinephrine (Fig. 2). Half-maximal relaxation occurred at $\sim 100 \mathrm{nM}$ hANF while Met-O-ANF was less effective as a relaxing agent, pro-

Table III. Plasma cGMP Levels following Single Bolus Injection of $A N F$

\begin{tabular}{lcc}
\hline & \multicolumn{2}{c}{ cGMP levels } \\
\cline { 2 - 3 } & Prior & Post \\
\hline & $n M$ & $n M$ \\
Vehicle & $9.8 \pm 1.1$ & $10.6 \pm 2.1$ \\
hANF & $15.7 \pm 4.0$ & $79.1 \pm 15.2^{*}$ \\
Met-O-ANF & $14.1 \pm 1.6$ & $15.5 \pm 2.6$
\end{tabular}

Plasma cGMP levels of Wistar rats 5 min after injection of the vehicle (acetic acid) or $2 \mu \mathrm{g}$ of either hANF or Met-O-ANF. ${ }^{*} P<0.001$, compared to control values. The data are expressed as mean $\pm \mathrm{SEM}$, $n=4$. 
Table IV. Time Course of Plasma cGMP Levels after Injection of $2.0 \mu \mathrm{g} \mathrm{Met}-\mathrm{O}-\mathrm{ANF}$

\begin{tabular}{lccccc}
\hline & \multicolumn{5}{c}{ Time } \\
\cline { 2 - 6 } & $\begin{array}{c}5 \mathrm{~min} \\
(\text { control })\end{array}$ & $90 \mathrm{~s}$ & $3 \mathrm{~min}$ & $10 \mathrm{~min}$ & $30 \mathrm{~min}$ \\
\hline $\operatorname{cGMP}(\mu \mathrm{M})$ & 8.15 & 8.08 & 8.28 & 7.62 & 5.77 \\
$\pm \mathrm{SEM}$ & \pm 1.04 & \pm 1.44 & \pm 0.40 & \pm 0.66 & \pm 0.43
\end{tabular}

Plasma cGMP levels of Wistar rats were measured at different time intervals after an injection of $2.0 \mu \mathrm{g}$ of Met-O-ANF. The vehicle (acetic acid) was injected as a control, and a blood sample was taken 5 min later. Data are expressed as means \pm SEM, $n=5$ or 10 (per control).

ducing only $\sim 14 \%$ relaxation at $100 \mathrm{nM}$. Its onset of action and its time course appeared to be slower than with hANF, but had an almost equivalent maximal effect on vasorelaxation. In fact, a complete relaxation was achieved with Met-O-ANF after an additional two minutes of observation (unpublished data).

cGMP production by different kidney fractions. As demonstrated previously (18), hANF elicited a large elevation of cGMP both in rat and canine glomeruli (Figs. 3 and 4). It has to be noticed that in glomeruli, the only renal fraction in which studies can be done both in dog and rat, a similar response was obtained in both species. Met-O-ANF stimulated cGMP production in glomeruli significantly less in both rat and dog kidneys (Figs. 3 and $4 a$ ). To explore the cGMP responsiveness to ANF and its analogues, we have proceeded with tubular fractions from dog kidneys. cGMP levels increased signifcantly in thick ascending limb both with hANF and Met-OANF (Fig. 4 b). In this tissue, the difference between the two analogues was only slight and reached only $20 \%$ with the highest dose of ANF. In the collecting duct, ANF increased cGMP two- to threefold while Met-O-ANF did not increase cGMP significantly (Fig. $4 c$ ).

cGMP levels in cultured aortic smooth muscle and endothelial cells. As reported previously (16), hANF increased intraand extracellular cGMP levels in cultured smooth muscle cells in a dose-dependent manner, with up to 75-fold stimulation of extracellular cGMP occurring at a concentration of $1 \mu \mathrm{M}$ hANF (Fig. 5 a). Met-O-ANF was less potent than hANF in

Table V. Plasma cGMP Levels Determined 5 Min after a Cumulative Dose of $3.5 \mu \mathrm{g}$ of $A N F$

\begin{tabular}{lrrrr}
\hline & $\operatorname{CGMP}(n M)$ \\
\hline Vehicle & $6.0 \pm 1.3$ & 7 & & 7 \\
hANF & $33.7 \pm 4.5$ & 」 & 7 & $\ddagger$ \\
Met-O-ANF & $11.9 \pm 2.4$ & & J & \rfloor
\end{tabular}

Successive cumulative doses $(0.5,1.0,2.0 \mu \mathrm{g})$ of hANF or Met-OANF were injected into Wistar rats at 20-min intervals. Blood samples for the CGMP measurements were taken 5 min after the last injection. ${ }^{*} P<0.01,{ }^{\ddagger}$ Not significant by analysis of variance, but significant when analyzed by the rank-order Wilcoxon test. The data are expressed as mean \pm SEM, $n=4$.

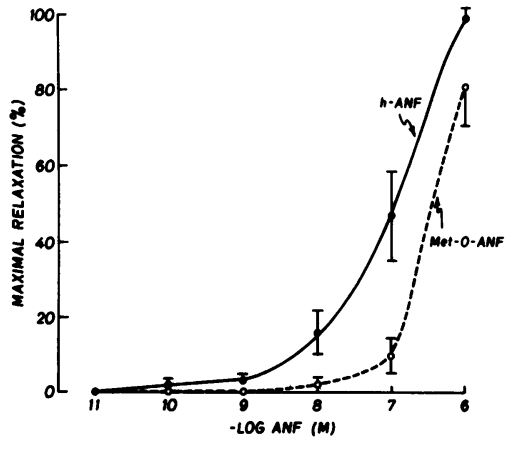

Figure 2. Dose-response curve of relaxation evoked by hANF and Met-O-ANF in rat aortic strips previously contracted by norepinephrine. The values are means \pm SEM, $n=6$. augmenting cGMP in these cells, evoking only a 25 -fold increase at a concentration of $1 \mu \mathrm{M}$. The results demonstrated in Fig. $5 a$ include the means of 16 different experiments obtained in cells at the passages between 14 to 20 derived from different stocks of original cells. As could be expected from the higher variability observed in response to hANF, the response to this parent compound varied from undistinguishable from that to Met-O-ANF to fivefold higher. These results suggest that the heterogeneity of the response between ANF and Met-O-ANF may also be due to the difference in the cell stock, cell growth, origin and/or passages.

Stimulation of cultured bovine endothelial cells with hANF $(1 \mu \mathrm{M})$ resulted in a 15 -fold rise in extracellular cGMP levels but only an 8-fold increase was observed after incubation with Met-O-ANF $(P<0.05$; Fig. $5 b)$.

\section{Discussion}

Natriuresis and diuresis were the first actions of ANF to be reported in the literature (37). Since then, many studies have been undertaken to elucidate the mechanisms of its natriuretic action, which was always coupled to the diuretic effect.

We report here a dissociation of natriuresis and diuresis. An analogue of human ANF-(99-126), Met-O-ANF, which is oxidized at methionine position 110 , completely loses its natriuretic properties at doses that produce a significant $(P<0.05)$ increase in diuresis (Fig. 1). In contrast to escalating doses of hANF, which correlate most significantly with diuresis $(r$ $=0.58)$ and natriuresis $(r=0.60)$, the same doses of Met-OANF correlate only with diuresis $(r=0.44)$ but not with natriuresis $(r=-0.11$; Table I). Injection of Met-O-ANF results in a loss of the highly-significant correlation between natriuresis and diuresis that is observed with hANF. It can be seen in

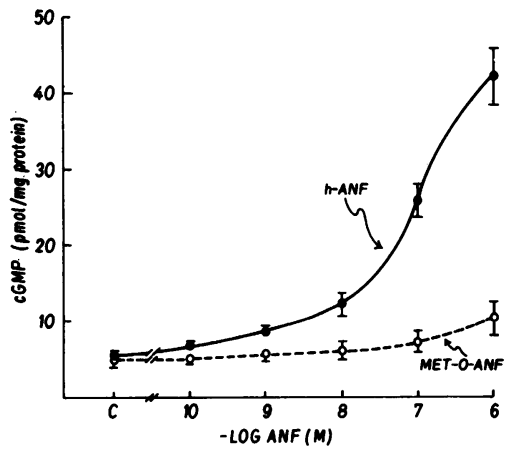

Figure 3. Effect of hANF and Met-O-ANF on CGMP levels in rat glomeruli. The glomeruli have been isolated as described in Methods. The incubation of glomeruli in presence of increasing concentration of ANF was performed in the presence of $0.5 \mathrm{mmol}$ MIX for a period of $5 \mathrm{~min}$. 

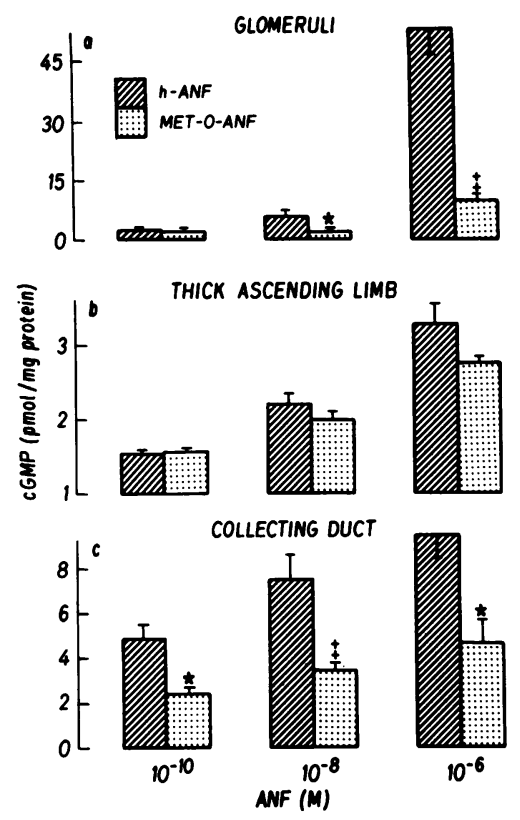

Figure 4. Effect of Met-O-ANF and hANF on cGMP production in different kidney fractions. cGMP generation by $(a)$ glomeruli, $(b)$ thick ascending limb, and $(c)$ collecting duct after stimulation with either hANF ( hatched columns) or Met-OANF (dotted columns). The data are the means of four to five ( \pm SEM) experiments. $* P<0.05$; $\ddagger P<0.01$ when compared to hANF.

Fig. 1 that the profile of the dose response of diuresis is different between hANF and Met-O-ANF. The diuresis with Met-O-ANF is slower in its onset and persists in the postinjection control period, suggesting a delayed onset and prolonged action of Met-O-ANF. It cannot be ascertained at the present whether or not this delayed and prolonged action of Met-OANF is related to receptor heterogeneity, as discussed below, or due to a prolonged stimulation of particulate guanylate cyclase which we have observed previously $(38,39)$.

To the best of our knowledge, this is the first report of a diuretic action of ANF without simultaneous natriuresis. It suggests that the diuretic mechanism is at least partially independent of sodium excretion. On the other hand, this analogue is as effective as ANF in lowering blood pressure and is only slightly less vasorelaxing.

cGMP has been shown to be a marker of the biological activity of ANF and may mediate its effects (16). We have

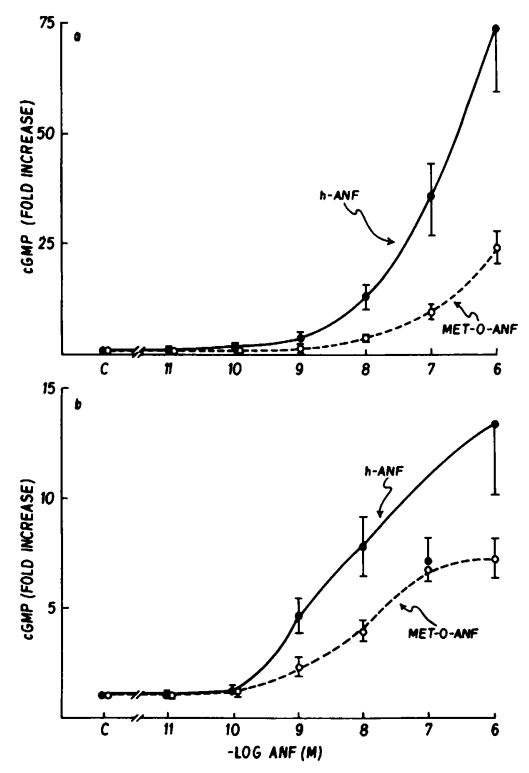

Figure 5. cGMP levels in $(a)$ rat aortic smooth muscle cells $(n=16)$ and $(b)$ bovine aortic endothelial cells $(n=8)$ after stimulation by either hANF or Met-OANF. The values are means \pm SEM. reported previously that bolus injections and infusions of ANF in rats, monkeys and humans increase plasma and urinary cGMP (15-17). Actually, the minimum dose of ANF needed to elevate cGMP in plasma is even lower than that required to stimulate diuresis and natriuresis (40). Met-O-ANF enhanced diuresis at doses that did not affect plasma or urinary cGMP levels. At first glance, these results are compatible with the notion that ANF uses another second messenger system to express its diuretic function. ANF has been reported to inhibit adenylate cyclase activity (41). However, we did not observe any significant changes of cAMP levels in our previous investigations (17), or in pilot experiments using Met-O-ANF (unpublished data). LY83583, an inhibitor of particulate guanylate cyclase, has no effect on the biological potency of ANF in vascular strips, yet only partial inhibition of this enzyme was achieved with this agent in that study (42).

Nevertheless, it is conceivable that the diuretic effect of ANF is exerted via its interaction with particulate guanylate cyclase at a tubular site where a rise in intracellular cGMP does not lead to its increase in urinary excretion. Such a situation would be analogous to the long-known difference between the effects of parathormone (PTH) and antidiuretic hormone (ADH) on urinary cAMP levels. Although both hormones are agonists of renal adenylate cyclase, with PTH stimulating it in the cortex and ADH doing likewise in the medulla, only the actions of PTH are reflected by urinary cAMP increases (43, 44). Moreover, the diuretic potency of Met-O-ANF dissociated from natriuresis is suggestive of an effect on free water clearance. This component of ANF's diuretic activity could be mediated via an inhibition of ADH secretion, which has been reported (45-48), or via its tubular effect (49). Receptors for ANF have been described in various sections of the medulla $(12,50)$. Our results indicate that such an anti-ADH action of ANF, whether or not related to the stimulation of particulate guanylate cyclase, is not reflected by urinary or plasma cGMP levels. Analyzing different dog nephron segments (Fig. $4 b$ ), we showed that the potency of ANF and Met-O-ANF is similar in one part of the tubule, the thick ascending loop. It would appear that although quantitatively this tissue does not contribute to urinary increases of cGMP, it is compatible with the possibility that at least part of the diuretic action of ANF is exerted at this part of the tubule.

The dissociation of natriuresis and diuresis in this study indicates that ANF's renal effects are exerted at several levels. In addition to its action on glomeruli, where we demonstrated a much lesser effect of Met-O-ANF, both substances appear to be equally potent at the level of diuresis not accompanied by natriuresis, i.e., free water clearance. The natriuretic effect of ANF, which appears to be faithfully reflected by cGMP in urine, is apparently exerted at a level of the tubule where Met-O-ANF is devoid of any significant potency (Fig. $4 a$ and c). This is compatible with the data of other investigators and suggests that the natriuretic action depends on the effect on glomeruli as well as on the action at the lowest level of the tubule $(10,27)$.

This report illustrates that a similar decrease of blood pressure can be achieved by Met-O-ANF and hANF. Whether this hypotensive action is mediated via a fall in cardiac output or vasodilation is still not entirely resolved; however, it is not accompanied by an increase of plasma cGMP in the case of Met-O-ANF. Again, this observation could give the impression that cGMP generation is not related to this biological 
function of ANF. These in vitro experiments have demonstrated that ANF and Met-O-ANF have an ability to stimulate particulate guanylate cyclase in vascular smooth muscle cells, resulting in an increase of cGMP levels. It has been previously suggested that Met-O-ANF does not increase cGMP levels at all in cultured vascular smooth muscle cells. In the experiments by Hirata et al. (29), the maximal doses used were lower than in this publication. In addition, we have observed in our own experiments high variability in the degree of the increases of cGMP observed between ANF and Met-O-ANF, as mentioned in Results. This variability can be attributed to the degree of passage of the cells or their growth state, although the exact mechanisms for this heterogeneity of response are not understood at the present time. The effect of the cell synchronization and cell growth on the expression of the particulate guanylate cyclase is at the present time under active investigation in our laboratory. It has been recently reported that different tissues as well as subcloning of the same cell-type result in a differential expression of ANF receptors and the responsiveness to ANF in its ability to increase cGMP levels. This differential expression of ANF receptors (51) may also be involved in the observed variability of the response to $\mathrm{hANF}$ and Met-O-ANF. The in vivo effects could be also affected by differential modification of levels and/or clearance of endogenous ANF by the two compounds (52), but the in vitro studies reported here support the notion of real heterogeneity of cGMP effector system.

The effects of hANF and Met-O-ANF are also distinct in cultured cells, where almost one order of magnitude of lower potency is observed with Met-O-ANF. Met-O-ANF is able to raise plasma cGMP levels but only with higher doses. We have recently observed that sodium nitroprusside, a known vasodilator, at doses that induce vasodilation and a reduction of blood pressure equivalent to that caused by hANF, does not elicit an increase of plasma cGMP in humans $(39,53)$ although its mechanism of action is clearly related to the stimulation of soluble guanylate cyclase in smooth muscle cells (54-56). We have already shown that sodium nitroprusside, although able to increase intracellular and extracellular cGMP levels in smooth muscle cells in vitro, does not modify cGMP levels in endothelial cells (16). These data suggest that the origin of augmentation of plasma cGMP is in endothelial rather than in smooth muscle cells. cGMP, which is mediating vasodilation in smooth muscle cells, could then not egress in sufficient quantities to alter plasma cGMP levels. Thus, an agonist such as hANF could lead to only an apparent parallelism between plasma cGMP levels and its vasodilatory potency. This parallelism, in fact, could be secondary to its endothelial site of action and could explain why Met-O-ANF has similar vasorelaxant and hypotensive potencies as hANF without changing plasma cGMP levels.

The presence of two or three types of ANF-receptors has been demonstrated (57-61), with only one of them being apparently linked to particulate guanylate cyclase. The relative density of these two receptors apparently varies from tissue to tissue (62). It is also conceivable that the coupling of the receptor to the guanylate cyclase itself may vary. The observations in the present study support the notion of the heterogeneity of the effector system of ANF in different tissues. At the level of cGMP generation as well as at the level of biological effects, the oxidized analogue of ANF and the parent compound vary in activity from very similar to clearly distinct degrees of potency. The data also show that urinary and plasma cGMP levels strongly correlate with natriuresis induced by ANF, but do not reflect its hypotensive and diuretic potency. These results also indicate that the diuretic and natriuretic actions of ANF are exerted at distinct sites of the nephron. The relationship between the heterogeneity of the effector system and the biological effects demonstrated in the present study deserves further investigation.

\section{Acknowledgments}

The authors thank Dr. Patrick Vinay, University of Montreal, for providing the different kidney fractions, and Suzanne Cossette, Regis Tremblay, and Carole Long for their excellent technical assistance. Gratitude is also extended to Louise Chevrefils and Micheline Caron for so capably typing this manuscript, to Ovid da Silva for editing it, and to Gaetan Thibault and Ernesto L. Schiffrin for valuable comments.

Roland C. Willenbrock is a recipient of a fellowship (Wi814/1-1) from the Deutsche Forschungsgemeinschaft and Johanne Tremblay is a scholar of Fonds de Recherche en Sante du Quebec. This work was supported by the Medical Research Council of Canada by a grant to the Multidisciplinary Group on Hypertension and MA-9299, as well as by the Canadian Heart Foundation.

\section{References}

1. Atlas, S. A. 1986. Atrial natriuretic factor: a new hormone of cardiac origin. Recent Progress in Hormone Research. 42:207-249.

2. Genest, J., and M. Cantin. 1987. Atrial natriuretic factor. Circulation. 75(Suppl. I):I1 18-I124.

3. Needleman, P., and J. E. Greenwald. 1986. Atriopeptin: a cardiac hormone intimately involved in fluid, electrolyte, and bloodpressure homeostasis. N. Engl. J. Med. 314:828-834.

4. Ishihara, T., K. Aisaka, K. Hattori, S. Hamasaki, M. Morita, T. Noguchi, K. Kangawa, and H. Matsuo. 1985. Vasodilatory and diuretic actions of $\alpha$-human atrial natriuretic polypeptide ( $\alpha$-hANP). Life Sci. 36:1205-1215.

5. Garcia, R., G. Thibault, J. Gutkowska, M. Cantin, and J. Genest. 1985. Changes of regional blood flow induced by atrial natriuretic factor (ANF) in conscious rats. Life Sci. 36:1687-1692.

6. Fried, T. A., R. N. McCoy, R. W. Osgood, and J. H. Stein. 1986. Effect of atriopeptin II on determinants of glomerular filtration rate in the in vitro perfused dog glomerulus. Am. J. Physiol. 250:F1119F1122.

7. Marin-Grez, M., J. T. Fleming, and M. Steinhausen. 1986. Atrial natriuretic peptide causes pre-glomerular vasodilatation and post-glomerular vasoconstriction in rat kidney. Nature (Lond.). 324:473-476.

8. Camargo, M. J. F., H. D. Kleinert, S. A. Atlas, J. E. Sealey, J. H. Laragh, and T. Maack. 1984. Ca-dependent hemodynamic and natriuretic effects of atrial extract in isolated rat kidney. Am. J. Physiol. 246:F447-F456.

9. Briggs, J. P., B. Steipe, G. Schubert, and J. Schnermann. 1982. Micropuncture studies of the renal effects of atrial natriuretic substance. Pfluegers Arch. Eur. J. Physiol. 395:271-276.

10. Sonnenberg, H., U. Honrath, C. K. Chong, and D. R. Wilson. 1986. Atrial natriuretic factor inhibits sodium transport in medullary collecting duct. Am. J. Physiol. 250:F963-F966.

11. Springate, J. E., R. D. Fildes, S.-K. Hong, L. G. Feld, and M. Acara. 1987. Renal effects of atrial natriuretic factor in domestic fowl. Life Sci. 40:915-920.

12. De Lean, A., P. Vinay, and M. Cantin. 1985. Distribution of atrial natriuretic factor receptors in dog kidney fractions. FEBS (Fed. Eur. Biochem. Soc.) Lett. 193:239-242.

13. Butlen, D., M. H. Mistaoui, and F. Morel. 1987. Atrial natriuretic peptide receptors along the rat and rabbit nephrons: [125-I] $\alpha$-rat 
atrial natriuretic peptide binding in microdissected glomeruli and tubules. Pfluegers Arch. Eur. J. Physiol. 408:356-365.

14. Burnett, J. C., Jr., J. P. Granger, and T. J. Opgenorth. 1984. Effects of synthetic atrial natriuretic factor on renal function and renin release. Am. J. Physiol. 247:F863-F866.

15. Hamet, P., J. Tremblay, S. C. Pang, R. Garcia, G. Thibault, J. Gutkowska, M. Cantin, and J. Genest. 1984. Effect of native and synthetic atrial natriuretic factor on cyclic GMP. Biochem. Biophys. Res. Commun. 123:515-527.

16. Hamet, P., J. Tremblay, S. C. Pang, R. Skuherska, E. L. Schiffrin, R. Garcia, M. Cantin, J. Genest, R. Palmour, F. R. Ervin, S. Martin, and R. Goldwater. 1986. Cyclic GMP as mediator and biological marker of atrial natriuretic factor. J. Hypertens. 4(Suppl. 2):S49S56.

17. Gerzer, R., H. Witzgall, J. Tremblay, J. Gutkowska, and P. Hamet. 1985. Rapid increase in plasma and urinary cGMP after bolus injection of atrial natriuretic factor in man. J. Clin. Endocrinol. Metab. 61:1217-1219.

18. Tremblay, J., R. Gerzer, P. Vinay, S. C. Pang, R. Beliveau, and P. Hamet. 1985. The increase of cGMP by atrial natriuretic factor correlates with the distribution of particulate guanylate cyclase. FEBS (Fed. Eur. Biochem. Soc.) Lett. 181:17-22.

19. Ardaillou, N., M.-P. Nivez, and R. Ardaillou. 1986. Stimulation of cyclic GMP synthesis in human cultured glomerular cells by atrial natriuretic peptide. FEBS (Fed. Eur. Biochem. Soc.) Lett. 204:177-182.

20. Ballermann, B. J., R. L. Hoover, M. J. Karnovsky, and B. M. Brenner. 1985. Physiologic regulation of atrial natriuretic peptide receptors in rat renal glomeruli. J. Clin. Invest. 76:2049-2056.

21. Winquist, R. J., E. P. Faison, S. A. Waldman, K. Schwartz, F. Murad, and R. M. Rapoport. 1984. Atrial natriuretic factor elicits an endothelium-independent relaxation and activates particulate guanylate cyclase in vascular smooth muscle. Proc. Natl. Acad. Sci. USA. 81:7661-7664.

22. Ohlstein, E. H., and B. A. Berkowitz. 1985. Cyclic guanosine monophosphate mediates vascular relaxation induced by atrial natriuretic factor. Hypertension. 7:306-310.

23. Hirata, Y., M. Tomita, H. Yoshimi, and M. Ikeda. 1984. Specific receptors for atrial natriuretic factor (ANF) in cultured vascular smooth muscle cells of rat aorta. Biochem. Biophys. Res. Commun. 125:562-568.

24. Kurtz, A., R. Della Bruna, J. Pfeilschifter, R. Taugner, and C. Bauer. 1986. Atrial natriuretic peptide inhibits renin release from juxtaglomerular cells by a cGMP-mediated process. Proc. Natl. Acad. Sci. USA. 83:4769-4773.

25. Oikawa, S., M. Imai, Y. Tawaragi, H. Nakazato, and H. Matsuo. 1985. Structure of dog and rabbit precursors of atrial natriuretic polypeptides deduced from nucleotide sequence of cloned cDNA. Biochem. Biophys. Res. Commun. 132:892-899.

26. Vlasuk, G. P., J. Miller, G. H. Bencen, and J. A. Lewicki. 1986. Structure and analysis of the bovine atrial natriuretic peptide precursor gene. Biochem. Biophys. Res. Commun. 136:396-403.

27. Ballermann, B. J., and B. M. Brenner. 1985. Biologically active atrial peptides. J. Clin. Invest. 76:2041-2048.

28. Shechter, Y. 1986. Selective oxidation and reduction of methionine residues in peptides and proteins by oxygen exchange between sulfoxide and sulfide. J. Biol. Chem. 261:66-70.

29. Hirata, Y., M. Tomita, S. Takada, and H. Yoshimi. 1985. Vascular receptor binding activities and cyclic GMP responses by synthetic human and rat atrial natriuretic peptides (ANP) and receptor down-regulation by ANP. Biochem. Biophys. Res. Commun. 128:538-546

30. Steiner, A. L. 1974. Assay of cyclic nucleotides by radioimmunoassay methods. Methods Enzymol. 38:96-105.

31. Richman, R. A., G. S. Kopf, P. Hamet, and R. A. Johnson. 1980. Preparation of cyclic nucleotide antisera with thyroglobulin-cyclic nucleotide conjugates. J. Cyclic Nucleotide Res. 6:461-468.

32. Vinay, P., A. Gougoux, and G. Lemieux. 1981. Isolation of a pure suspension of rat proximal tubules. Am. J. Physiol. 241:F403F411.

33. Baverel, G., M. Forissier, and M. Pellet. 1980. Lactate and pyruvate metabolism in dog renal outer medulla. Effects of oleate and ketone bodies. Int. J. Biochem. 12:163-168.

34. Vinay, P., C. Manillier, L. Lalonde, G. Thibault, Y. Boulanger, A. Gougoux, and M. Cantin. 1987. Comparative effect of ANF and various diuretics on isolated nephron segments. Kidney Int. 31:946955.

35. Franks, D. J., J. Plamondon, and P. Hamet. 1984. An increase in adenylate cyclase activity precedes DNA synthesis in cultured vascular smooth muscle cells. J. Cell. Physiol. 119:41-45.

36. Garcia, R., G. Thibault, M. Cantin, and J. Genest. 1984. Effect of a purified atrial natriuretic factor on rat and rabbit vascular strips and vascular beds. Am. J. Physiol. 247:R34-R39.

37. De Bold, A. J., H. B. Borenstein, A. T. Veress, and H. Sonnenberg. 1981. A rapid and potent natriuretic response to intravenous injection of atrial myocardial extract in rats. Life Sci. 28:89-94.

38. Tremblay, J., S. C. Pang, E. L. Schiffrin, J. Gutkowska, J. Cusson, P. Larochelle, and P. Hamet. 1987. Particulate guanylate cyclase: target enzyme of atrial natriuretic factor. In Biologically Active Atrial Peptides. Vol. 1. B. M. Brenner, and J. H. Laragh, editors. Raven Press, New York. 255-257.

39. Tremblay, J., R. Willenbrock, J. R. Cusson, P. Larochelle, P. W. Schiller, F. H. H. Leenen, R. Palmour, F. Ervin, E. Testaert, and P. Hamet. 1988. Role of particulate guanylate cyclase activation in the expression of biological actions of ANF. In Biological and Molecular Aspects of Atrial Factors. UCLA Symposia Series. Vol. 81. P. Needleman, editor. Alan R. Liss, Inc., New York. 97-108.

40. Cusson, J. R., P. DuSouich, P. Hamet, E. L. Schiffrin, O. Kuchel, J. Tremblay, M. Cantin, J. Genest, and P. Larochelle. 1988. Effects and pharmacokinetics of bolus injections of atrial natriuretic factor in normal volunteers. J. Cardiovasc. Pharmacol. 11:635-642.

41. Anand-Srivastava, M. B., D. J. Franks, M. Cantin, and J. Genest. 1984. Atrial natriuretic factor inhibits adenylate cyclase activity. Biochem. Biophys. Res. Commun. 121:855-862.

42. Ng, D. D. W., and J. Diamond. 1986. Effects of LY83583 on atriopeptin II induced relaxation and cyclic GMP elevation in the rabbit aortic rings. Proc. West. Pharmacol. Soc. 29:113-116.

43. Dousa, T. P., S. V. Shah, and H. E. Abboud. 1980. Potential role of cyclic nucleotides in glomerular pathophysiology. Adv. Cyclic Nucleotide Res. 12:285-299.

44. Aurbach, G. D. 1980. Receptor-adenylate cyclase components: abnormalities in clinical medicine. Adv. Cyclic Nucleotide Res. 12:1-9.

45. Samson, W. K. 1985. Atrial natriuretic factor inhibits dehydration and hemorrhage-induced vasopressin release. Neuroendocrinology. 40:277-279.

46. Januszewicz, P., J. Gutkowska, A. De Lean, G. Thibault, R. Garcia, J. Genest, and M. Cantin. 1985. Synthetic atrial natriuretic factor induces release (possibly receptor-mediated) of vasopressin from rat posterior pituitary. Proc. Soc. Exp. Biol. Med. 178:321-325.

47. Obana, K., M. Naruse, T. Inagami, A. B. Brown, K. Naruse, F. Kurimoto, H. Sakurai, H. Demura, and K. Shizume. 1985. Atrial natriuretic factor inhibits vasopressin secretion from rat posterior pituitary. Biochem. Biophys. Res. Commun. 132:1088-1094.

48. Lee, J., J. Q. Feng, R. L. Malvin, B. S. Huang, and R. J. Grekin. 1987. Centrally administered atrial natriuretic factor increases renal water excretion. Am. J. Physiol. 252:F1011-F1015.

49. Ishikawa, S.-e., T. Saito, K. Okada, T. Kuzuya, K. Kangawa, and $\mathrm{H}$. Matsuo. 1985. Atrial natriuretic factor increases cyclic GMP and inhibits cyclic AMP in rat renal papillary collecting tubule cells in culture. Biochem. Biophys. Res. Commun. 130:1147-1153.

50. Bianchi, C., J. Gutkowska, R. Garcia, G. Thibault, J. Genest, and M. Cantin. 1987. Localization of ${ }^{125} \mathrm{I}$-atrial natriuretic factor (ANF)-binding sites in rat renal medulla. A light and electron microscope autoradiographic study. J. Histochem. Cytochem. 35:149-153.

51. Leitman, D. C., J. W. Andresen, R. M. Catalano, S. A. Waldman, J. J. Tuan, and F. Murad. 1988. Atrial natriuretic peptide bind- 
ing, cross-linking, and stimulation of cyclic GMP accumulation and particulate guanylate cyclase activity in cultured cells. J. Biol. Chem. 263:3720-3728.

52. Maack, T., M. Suzuki, F. A. Almeida, D. Nussenzveig, R. M. Scarborough, G. A. McEnroe, and J. A. Lewicki. 1987. Physiological role of silent receptors of atrial natriuretic factor. Science (Wash. DC). 238:675-678.

53. Roy, L. F., P. Larochelle, P. Hamet, R. I. Ogilvie, and F. H. H. Leenen. 1988. Hemodynamic effects of atrial natriuretic factor (ANF) versus sodium nitroprusside (NIP) in healthy men. Proceedings of the 12th Scientific Meeting of the International Society of Hypertension, Kyoto, Japan, 22-26 May 1988, No. 1128.

54. Schultz, K.-D., K. Schultz, and G. Schultz. 1977. Sodium nitroprusside and other smooth muscle-relaxants increase cyclic GMP levels in rat ductus deferens. Nature (Lond.).265:750-751.

55. Kimura, H., C. K. Mittal, and F. Murad. 1975. Activation of guanylate cyclase from rat liver and other tissues by sodium azide. $J$. Biol. Chem. 250:8016-8022.

56. Bohme, E., H. Graf, and G. Schultz. 1978. Effects of sodium nitroprusside and other smooth muscle relaxants on cyclic GMP formation in smooth muscle and platelets. Adv. Cyclic Nucleotide Res. 9: 131-143.

57. Leitman, D. C., J. W. Andresen, T. Kuno, Y. Kamisaki, J. K.
Chang, and F. Murad. 1986. Identification of multiple binding sites for atrial natriuretic factor by affinity cross-linking in cultured endothelial cells. J. Biol. Chem. 261:11650-11655.

58. Schenk, D. B., M. N. Phelps, J. G. Porter, F. Fuller, B. Cordell, and J. A. Lewicki. 1987. Purification and subunit composition of atrial natriuretic peptide receptor. Proc. Natl. Acad. Sci. USA. 84:15211525.

59. Takayanagi, R., R. M. Snajdar, T. Imada, M. Tamura, K. N. Pandey, K. S. Misono, and T. Inagami. 1987. Purification and characterization of two types of atrial natriuretic factor receptors from bovine adrenal cortex: guanylate cyclase-linked and cyclase-free receptors. Biochem. Biophys. Res. Commun. 144:244-250.

60. Paul, A. K., R. B. Marala, R. K. Jaiswal, and R. K. Sharma. 1987. Coexistence of guanylate cyclase and atrial natriuretic factor receptor in a 180-kD protein. Science (Wash. DC). 235:1224-1226.

61. Pandey, K. N., T. Inagami, and K. S. Misono. 1987. Three distinct forms of atrial natriuretic factor receptors: kidney tubular epithelium cells and vascular smooth muscle cells contain different types of receptors. Biochem. Biophys. Res. Commun. 147:1146-1152.

62. Napier, M. A., M. T. Lipari, and R. L. Vandlen. 1986. Tissue and species distribution of receptor subtypes for atrial natriuretic factor. In Proceedings of the 34th Colloquium on Protides of the Biological Fluids. H. Peeters, editor. Pergamon Press, Oxford, England. 217-220. 